\title{
Iurynets J.L.*
}

DOI: 10.25108/2304-1730-1749.iolr.2017.50.274-303

\section{Restriction of Russian information and cultural content in Ukraine: conventional measurement}

\begin{abstract}
In the conditions of a hybrid war, information warfare is an important component. In connection with Russia's aggression against Ukraine, the latter is forced to seriously restrict the dissemination of Russian information and cultural content in Ukraine, which is criticized by some democratic institutions. In this regard, it is necessary to assess the legitimacy of these restrictions in the context of Article 10 "Freedom of Expression" of the 1950 Convention on the Protection of Human Rights and Fundamental Freedoms.

Keywords: Convention for the Protection of Human Rights and Fundamental Freedoms of 1950; European Court of Human Rights; information war; Hostile propaganda; Freedom of expression; National security; Restrictions on information freedoms based on the Convention.
\end{abstract}

The Russian-Ukrainian conflict in the Crimea and the Donbass undermines the foundations of security throughout the world and requires reflection not only and, perhaps, not so much by Ukrainian society as outside of Ukraine, since the aggressor disseminates a large amount of unreliable information. Important resolutions have been fixed in the Resolution of the Parliamentary Assembly of the Council of Europe (PACE) of 12.10.2016, in particular: PACE reiterates its position that the annexation of the Crimea by the Russian Federation (RF) and the military intervention of Russian troops in Eastern Ukraine violate international law and principles, Supported by the Council of Europe $(\mathrm{CoE})$, as referred to in Assembly resolutions 2112 (2016); 2063 (2015); 1990 (2014); 1988 (2014) (Item

- Iurynets Julia Leonidovna - PhD in Law, Associate Professor, Associate Professor of the Department of Constitutional and Administrative Law Faculty of the National Aviation University, Kiev (Ukraine). E-mail: belkinajulia@ list.ru 
2); "DNR" and "LNR", created with the support and control of the Russian Federation, do not have any legitimacy in accordance with Ukrainian or international law (Item 3); the well-documented role of the Russian military in taking control and control of these regions is confirmed, despite strong resistance to the legitimate authority of Ukraine, and the complete dependence of the "DNR" and "LNR" on the Russian Federation in terms of material, technical, financial and administrative (Item 5) (Cited by source [1]).

Similar conclusions were drawn by the international competent bodies regarding the role of Armenia in the so-called Nagorno-Karabakh Republic ("NKR"). Thus, in the judgment of the European Court of Human Rights of 16.06.2015 on the case "Chiragov and Others v. Armenia" (Application № 13216/05)" it is stated that "all of the above reveals that the Republic of Armenia, from the early days of the Nagorno-Karabakh conflict, has had a significant and decisive influence over the "NKR", that the two entities are highly integrated in virtually all important matters and that this situation persists to this day. In other words, the "NKR" and its administration survives by virtue of the military, political, financial and other support given to it by Armenia which, consequently, exercises effective control over Nagorno-Karabakh and the surrounding territories, including the district of Lachin" (Item 186); occupation within the meaning of the 1907 Hague Regulations exists when a state exercises actual authority over the territory, or part of the territory, of an enemy state. The requirement of actual authority is widely considered to be synonymous to that of effective control (Item 96) (Cited by source [2]).

Thus, the European Court of Human Rights actually recognized the occupation of part of the territory of Azerbaijan ("NKR") by Armenia. It follows that Ukraine and Azerbaijan have much in common in solving problems of security and territorial integrity. According to the professor of the Sukhumi State University (Tbilisi) E. Kavtaradze, "the decision of the Ukrainian crisis will favorably affect the settlement of conflicts in the territories of Azerbaijan and Georgia". "If the fate of Ukraine is resolved positively, then the solution of the fate 
of conflicts in the territories of Azerbaijan and Georgia will also be positive", - he told "Interfax-Azerbaijan" [3]. As the Azerbaijani authors point out, "the occupation by Russia of Ukraine's territory creates the threat of repetition of similar steps against Azerbaijan" [4]. At the same time, some Azerbaijani authors see "the machinations of America" in the Ukrainian conflict, producing corresponding parallels with Azerbaijan [5]. Therefore, an objective analysis of the laws of social development in Ukraine is relevant for the public of Azerbaijan. Separate questions of the problem posed concerning the limitation of Russian information and cultural content were considered by the author in her article [6].

The aggression of the Russian Federation against Ukraine, whose presence (aggression) is recognized at the international level, in particular in the PACE Resolution of 12.10.2016, mentioned above, has such an essential component as «information war». As noted in the work [7], the anti-Ukrainian propaganda campaign revealed the insufficient formation of scientific and methodological grounds and explanations for actions in similar situations, demonstrated weak coordination of actions of state authorities, civil society, expert and scientific communities, journalists to counteract such campaigns. The purpose of the information war is to weaken the moral and material forces of the opponent or competitor and strengthen our own [7, p. 137]. Such insufficient attention to the information security of the country is Ukrainian scientist, Doctor of Law I. Sopilko called "epochal humanism" [8]. For the sake of justice, we must admit that this state of affairs is largely due to the fact that Ukraine too trustingly relied on the socalled Budapest Memorandum signed by the United States, Great Britain, Russia and Ukraine, by which the first three countries as the largest nuclear powers guaranteed territorial integrity, economic security and non-use Any weapon against Ukraine [9]. Unfortunately, at the moment these guarantees remain a fiction.

Secretary of the National Security and Defense Council of Ukraine (NSDC) A. Turchynov notes that the hybrid war paradigm is aimed at undermining and destroying the entire complex of social relations in the object of aggression, destroying the will to resist, including through information operations [10]. Israeli 
military instructor and political scientist Zvi Arieli points out that information is an inseparable part of any military campaign. Due to the fact that many modern wars are often not conducted on total destruction, and their goals are limited political achievements, information can play a decisive role both at the operational or operational-tactical level, and in terms of consolidating the results of the military company in legal and international Political plan [11].

Information and cultural components of warfare were mentioned in the treatise of the ancient Chinese philosopher and military leader Sun Tzu (VI century $\mathrm{BC})$ : "undermine the prestige of the leadership of the enemy and expose him at the right time to condemn the public"; "use for this purpose cooperation with the most vile and vilest people"; "fetter the will of the enemy's soldiers with songs and music»; «do everything possible to devalue the traditions of your enemies and undermine their faith in their gods" [12]. Thus, in a country that resists aggression, there is a natural need for restrictions and prohibitions on these impacts. However, these restrictions or prohibitions may face objections inherent in a democratic society. Therefore, it is relevant to analyze the acceptability of restrictions and prohibitions on relevant information and cultural content in a democratic society.

With all due respect to freedom of expression, freedom to disseminate and receive information, these freedoms are not absolute. Thus, in the French Declaration of the Rights of Man and the Citizen (1789, Article 11), which remains an integral part of the modern Constitution of France, it is stated: «Free communication to other thoughts is one of the precious human rights; So every citizen can freely express, write, print, bearing responsibility for the abuse of this freedom in cases prescribed by law» (highlighted by the author). In the decision of the US Supreme Court in the case of "Roth v. United States" states that " it is apparent that the unconditional phrasing of the First Amendment (to the US Constitution - the author's note) was not intended to protect every expression".

In the decision of the US Supreme Court in the case of "FCC v. Pacifica Foundation" recognized that the "content of respondent's broadcast, which was 'vulgar', 'offensive', and 'shocking', is not entitled to absolute constitutional 
protection in all contexts; it is therefore necessary to evaluate the FCC's (Federal Communications Commission - the author's note) action in light of the context of that broadcast".

The European standard for ensuring freedom of speech and their limitations is set forth in Article 10 of the Convention for the Protection of Human Rights and Fundamental Freedoms. This article includes two parts:

1) Everyone has the right to freedom of expression. This right shall include freedom to hold opinions and to receive and impart information and ideas without interference by public authority and regardless of frontiers. This Article shall not prevent States from requiring the licensing of broadcasting, television or cinema enterprises.

2) The exercise of these freedoms, since it carries with it duties and responsibilities, may be subject to such formalities, conditions, restrictions or penalties as are prescribed by law and are necessary in a democratic society, in the interests of national security, territorial integrity or public safety, for the prevention of disorder or crime, for the protection of health or morals, for the protection of the reputation or rights of others, for preventing the disclosure of information received in confidence, or for maintaining the authority and impartiality of the judiciary.

So, restrictions are possible, if they are established by law, necessary in a democratic society and applied, in particular, in the interests of national security, territorial integrity and/or public security. Consider in this light the legality of restrictions on information and cultural content of Russian origin and / or proRussian content.

Regarding the first criterion of restrictions - the establishment of the law - it should be noted that even in the Doctrine of Information Security of Ukraine, approved by Presidential Decree No. 514/2009 of 08.07.2009, threats to the information security of Ukraine, in particular, recognized negative information influences aimed at undermining Constitutional order, sovereignty, territorial integrity and inviolability of Ukraine's borders; use of the media (mass media), as well as the Internet to promote separatism on ethnic, linguistic, religious and/or 
other grounds; Dissemination of values and ways of life in the media, the cult of violence, cruelty, pornography, disregard for human and national dignity, etc. In the recommendations of the parliamentary hearings on "Problems of the development of Ukrainian book publishing, book distribution and the prospects of supporting book reading in Ukraine" approved by the Decree of the Verkhovna Rada of Ukraine of November 19, 2013, No. 695-VII, in particular, attention was paid to the decline in the competitiveness of the Ukrainian book and the rapid filling of most of the genre niches of the Ukrainian book market by an imported book, mainly from the Russian Federation. However, due to a false sense of "epochal humanism", these threats were not fixed and embodied legislatively. And only when, due to the aggression of the Russian Federation, the threats were justified, a number of relevant laws were adopted. Really Ukrainian law and practice went through the application of such prohibitions (restrictions), namely: retransmission of Russian broadcasters; Broadcasting (distribution) of TV and radio products produced by the Russian Federation; Import from the territory of the aggressor state, as well as temporarily occupied territory of Ukraine, publishing products, which can be distributed in the territory of Ukraine; Use of certain topics that are harmful to the national security of Ukraine, in the national television and radio product, in other media, including print media. Thus, the laws of Ukraine prohibit the dissemination in any way of Russian information and cultural content that popularizes or propagates the organs of the aggressor state and their individual actions justifying or recognizing the legitimate occupation of the territory of Ukraine, namely: the use of television and radio organizations to broadcast television programs produced after 01.08.1991. (The Law of Ukraine (hereinafter referred to as LU) "On Television and Radio Broadcasting", Part 2, Article 6), the distribution and demonstration of films with content on the subject matter (LU "On Cinematography”, Article 15-1), Materials in printed mass media (LU «On Press in Ukraine», Article 3) and book editions (Law on Publishing, Articles 28, 28-1). In addition, the norm of part 2 of Article 6 of the LU "On Television and Radio Broadcasting» prohibits the broadcasting of audiovisual works (films, telecasts, 
except for information and information-analytical telecasts), one of the participants of which is a person listed in the list of persons posing a threat to the national security of Ukraine.

Thus, these bans are provided for by law. That is, if, for example, the Russian TV channel demonstrates a map of Ukraine without the Crimea, then such a demonstration is aimed at securing this fact in the minds of the population and directly contradicts the norms of Ukrainian legislation, and if this channel otherwise can not by virtue of the legislation of the Russian Federation, then he has nothing to do In the television space of Ukraine.

At the same time, there are not enough similar restrictions (prohibitions) in the Law on Information Agencies regarding Russian news agencies and information originating from these agencies. After all, these are the same Russian news agencies that massively produced false and propaganda 'news' antiUkrainian orientation: 'crucified boy'; "the mother of the said crucified boy, who was tied to a tank and dragged across the square"; 'two slaves'; "gnawed bullfinch, unlike the tomtit of patriotic (yellow-blue - author's note) colors"; "drunken Negroes dance on Ukrainian tanks"; "Yatsenyuk (ex-Prime Minister of Ukraine note of the author) fought in Chechnya and participated in the torture and execution of Russian prisoners of war"; "Avdeevka is shelled by the Ukrainian army (which controls this city and provides life there - the author's note)" and others. Coordinator of the International Coalition "Stop Fascism in Russia" G. Obukhov calls such a submission of information «information terrorism". "By distorting the facts and falsifying the events", - the expert points out, - information terrorists affect the consciousness of people on a much larger scale than the plastid explosion (explosives are - the author's note), and this entails far more tragic consequences» [13]. There is no reason to allow these agencies to legitimately distribute this information in Ukraine (and in the rest of the world). Thus, the representative of Ukraine to the United Nations, Ambassador V. Yelchenko in his address to the UN on May 11, 2016 drew attention to the fact that "the cruel and vicious propaganda spread by the state-run media in Russia is one of the main 
elements of the hybrid aggression of the Russian Federation. There is a need to combat such phenomena as state propaganda of intolerance and hatred" [14]. Film director V. Mansky notes that Russian "propaganda not only gave birth to a war, it constantly heats up... while in Russia, it is difficult to resist this common absolute space of unlimited lies" [15].

With regard to the analysis of the legitimacy of restrictions on two other criteria (legitimate aim and necessity in a democratic society), we will consider the correspondence to these criteria in a relationship.

So, the doctor of legal sciences V. Lipkan points to the so-called white (formally - legal) hostile propaganda - frankly disloyal to the target entity, which is conducted by any media through official channels. On TV channels and in other state-owned media of the Russian Federation, there is an ongoing falsification of information, discrediting top officials in order to form a negative attitude, in particular to Ukraine... In fact, propaganda is a method of information struggle that provides for an active offensive information impact on the object with the aim of Making predetermined changes in the information space, which causes the corresponding changes in the reality space [16].

In the article mentioned above [7, p. 140] it is noted that in the information war against Ukraine, the Russian Federation applies practically the whole arsenal of influence on people's consciousness. In particular, observers note that, for example, all 23 years of Ukraine's independence on Crimean television antiUkrainian propaganda was conducted.

The Russian journalist A. Babchenko writes: "Putin's propaganda got all the nastiness out of people, turned all the worst into a good place, allowed murder, xenophobia, obscurantism, persecution, harassment, hatred, aggression, racial intolerance... - and it turned out to be incredibly effective... I am almost certain that not a single 'our Crimea' (the support of the citizens of the Russian Federation for the seizure of the Crimea - the author's note) would not have been possible without all these serials militia, investigators, murder, kidnapping, brigade, killers, corpses, 'investigation' about maniacs, about child abusers, about human meat in 3 
liter cans, constant pedaling of the dark sides of life" [17]. Obviously, it was no coincidence that in 2004 the President of the Russian Federation, V. Putin spoke out against the restrictions in the broadcast of scenes of violence on Russian television, noting in particular that as a result of such a ban "the patriotic education of minors will suffer, largely related to the demonstration of films about the exploits and courage of our compatriots" [18].

It should be noted here that, on the contrary, the Council of Europe has repeatedly spoken out for limiting the propaganda of violence and cruelty, in particular, in the Recommendation of the Committee of Ministers of the Council of Europe No. R (89) 7 of 27.04 .1989 "On the principles of distributing video recordings of violent, cruel or pornographic content", No. R (97) 19 of 30.10.1997 "On the display of violence in electronic media", No. R (97) 20 of 30.10.1997 “On inciting hatred". As for Ukraine, this propaganda, which was mainly imported into Ukrainian television by the Russian television and video product, was not timely assessed by the Ukrainian authorities as threatening, not only in terms of threat to public morality, but also in terms of a threat to national security.

Objective research indicates that separatism and consistent anti-Ukrainianness did not have any real roots in the Donbass or in the Crimea, but were introduced there from without, by Russian propaganda. So, the Russian researcher A. Akhmetov (2013) comes to the conclusion that the strengthening of institutions of power and the establishment in Ukraine of democratic procedures and ways of interaction between political institutions allowed to deactivate the problem of Russian separatism in the Crimea [19]. G. Starovoitova notes that the rights of the Russian-speaking majority in the Crimea are not violated by the Ukrainian authorities and the Crimea's problems are solved «without calling Ukraine's sovereignty»... but many people in Russia, including few influential politicians, did not want to accept the idea that Crimea is part of a neighboring state [20]. This same propaganda line continues even further (2017). Calling for the seizure of the territories of Ukraine and Kazakhstan, the 'figures' of the State Duma of the Russian Federation directly indicate that "it is necessary to conduct propaganda, 
not everything is lost in the so-called neighboring countries... The borders are not eternal, and we will return to the borders of the Russian state" [21]. A resident of Donetsk recalls the events of the 'Russian Spring' in 2014: "I remember this 'referendum'. A few days before, according to one of the Russian TV channels, the news anchor told that in Donetsk marks are placed on the homes of Russianspeaking citizens. My wife and I giggled then. What nonsense!.. Then this rubbish was seriously told to each other by people in a referendum... And we suddenly realized that the people began to go crazy in mass" [22].

Thus, the Russian propaganda has inflicted and causes a huge damage to the national security of Ukraine, in fact leads to the death of people, that is why the restriction of such propaganda corresponds to the legitimate goal - ensuring national security - and is necessary in a democratic society.

It should also be noted that Ukraine and the Russian Federation are formally members of the European Convention on Transfrontier Television. However, the Russian Federation has not ratified this Convention, does not consider itself bound by its terms. Thus, although according to Article 4 of this Convention, the parties to the Convention guarantee freedom of reception and do not limit the retransmission of software services in their territory that meet the conditions of the Convention, based on the principle of reciprocity, Ukraine is not obliged to adhere to this Convention in relation to the Russian Federation. For example, by analogy with Part 9 of Article 13 LU "On advertising", broadcasting (retransmission) of advertisements, which is contained in the programs and programs of foreign TV and radio broadcasting to the territory of Ukraine, if foreign TV and radio organizations DO NOT fall under the jurisdiction of EU member states or states that have ratified the Convention, - PROHIBITED.

It should be said that such challenges arose not only in front of Ukraine. So, the above-mentioned expert G. Obukhov points out that "today for the West and, in particular, for the United States, comes from Russia a threat that no one has dared to correctly qualify, and then begin to seek a solution to a very large problem and eliminate this threat. What Russia does in the information space abroad is no 
propaganda, it is real information terrorism and information diversions. Propaganda is the promotion and upholding of some ideologies or ideas that can be both political and non-political. Information terrorism is the deliberate distortion of facts and the falsification of real events" [13]. In this sense, it becomes quite understandable the statement of the Defense Minister of the Russian Federation S. Shoigu during the speech in the State Duma of the Russian Federation that the troops of information operations have been established in the military department of the Russian Federation [23].

The well-known Russian journalist and blogger Sasha Sotnik comments: “A civilized society has every possible leverage to fight the [Putin propaganda virus]. The first step was already made by Great Britain, having closed all accounts of the Putin propaganda channel "Russia Today". At the same time, "freedom-loving moans" [about freedom of speech] should not be misled by the Western public, since fascist propaganda is not only possible but necessary to be banned and eradicated by all possible means: close accounts, deny broadcasting licenses, expel propagandists with cameras and microphones - to your favorite "imperial homeland". Do not enter into a position, do not yield to screams and exhortations, and - especially - do not cooperate. In no case. Not allowed on the threshold. Drive into the neck from all sides. Propaganda of Putinism should be banned totally and legislatively".

Conclusions. The restriction of Russian information and cultural content in Ukraine as a country that has been aggressed by the Russian Federation and resisting this aggression is justified and permissible in the light of the Convention for the Protection of Human Rights and Fundamental Freedoms, as provided by law, corresponds to the legitimate goal of ensuring national security and is necessary in a democratic society. Sooner or later, the same problem will have to be solved beyond the borders of Ukraine. 


\section{References}

1. Istoricheskaya rezolyutsiya PACE po Rossii: polniy tekst [Historical resolution on Russia: full text]. Available at: http://news.liga.net/news/politics/ 13142341-istoricheskaya_rezolyutsiya_pase_po_rossii_polnyy_tekst.htm

2. The judgment of the ECHR Rights of 16.06.2015 on the case "Chiragov and Others v. Armenia" (Application no. 13216/05). Available at: http://www. refworld.org/cases, ECHR,5582d29d4.html

3. Reshenie krizisa v Ukraine otrazit'sya na konfliktakh v Azerbaijane i Gruzii. [Solution of crisis in Ukraine will be reflected in conflicts in Azerbaijan and Georgia. Available at:http://glavcom.ua/news/211776-reshenie-krizisa-v-ukraineotrazitsja-na-konflik tah -v-azerbajdzhane-i-gruzii---ekspert.html

4. "Perviy vrag tyurka - eto Rossiya... Azerbaijan - al'ternativa Rossii... Azerbaijan - ne Ukraina": Obzor bakinskikh SMI ["First enemy of Turks is Russia ... Azerbaijan is an alternative of Russia... Azerbaijan is not Ukraine"]: Review of Baku mass media. Available at: http://www.iarex.ru/articles/47003.html

5. Fatullayev E. Prevratit' Azerbaijan v Ukrainu za $\$ 32$ millions [To turn Azerbaijan into Ukraine for $\$ 32$ millions]. Available at: http://inosmi.ru/ sngbaltia/20140415/219577270.html

6. Iurynets J.L. "Informatsini viyni” Ukraini ta Rosii v kontekste st. 10 EKPL [Informational wars of Ukraine with Russia in context of Article 10 of ECHR] // Yuridichna gazeta [Legal newspaper]. 07.02.2017, no. 6 (556), pp. 22-24. Available at: http://yur-gazeta.com/publications/practice/ inshe/informaciyni-viyniukrayini-ta-rosiyi-v-konteksti-st10-ekpl.html

7. Gorban Y.O. Informatsiina viina proti Ukraini ta zasobi ii vedennya [Informational war against Ukraine and ways its conducting].Visnik NADU [Journal of NADU]. 2015, no. 1, pp. 136-141.

8. Sopilko I.M. Rol' Zakonu Ukraini "Pro osnovi natsionalnoi bezpeki Ukraini" v realizatsii derzhavnoi informatsiinoi politiki Ukraini [Role of the Law of Ukraine "On National Security of Ukraine" in implementing the state 
information policy Ukraine]. Yurid. nauk. Electron. zhurnal: Elektronne naukove fakhove vidannya [Legal Research Electronic Journal: Electronic scientific specialized edition]. 2014, no. 2, pp. 75-78.

9. Memorandum pro garantii bezpeki u zav'zku z priednannyam Ukraini do Dogovoru pro neprozpovsyudzhennya yadernoi zbroi [Memorandum on guarantees of the security in connection with joining Ukraine to the Treaty on the NonProliferation of Nuclear Weapons of 05.12.1994]. Available at: http://zakon3. rada.gov.ua/laws/show/998_158

10. Turchinov O. Natsional'na bezpeka Ukraini: vikliki ta prioriteti [National Security Ukraine: Challenges and Priorities]. Available at: http:// censor.net. ua/resonance/402074/natsonalna_bezpeka_ukrani_vikliki_ta_proriteti

11. Arieli Tsvi. Informatsionnaya voina: kak Ukraine pobedit' putinskuyu Rossiyu? [Information war: how Ukraine to win Putin's Russia?] / Obozrevatel' [Observer]. Available at: http://obozrevatel. com/blogs/78045-informatsionnayavojna-kak-ukraine-pobedit-putinskuyu-rossiyu.htm

12. Zhurnalistika yak zbroya masovogo znischennya: pro informatsiyunu vinu Rosii proti Ukraini zseredini [Journalism as a weapon of mass destruction: the information war against Ukraine Russia inside]. Available at: http:/grozanews.com.ua/?p=1399

13. Obukhov G. Informatsionniyu terrorizm [Informational terrorism]. Obozrevatel' [Observer]. Available at: https://www.obozrevatel.com/blogs/27468informatsionnyij-terrorizm.htm

14. Ukraina v OON ofitsial'no obvinila Rossiyu v podderzhke terrorizma [In the UN Ukraine officially accused Russia in supporting of terrorism]. Available at: http://hvylya.net/news/digest/ukraina-v-oon-ofitsialno-obvinila-rossiyu-v-pod derzhke -terrorizma.html

15. Manskiy V. To, chto ya uvidel v Donetske, - absolyutnaya fantasmogoriya [That I saw in Donetsk is absolute phantasmagoria] / Interview Radio "Liberty" Available at: http://www.radiosvoboda.org/a/28263681.html

16. Lipkan V. Zmist propaganda na suchasnomu etapi [Content propaganda 
nowadays]. Available at: http://my.obozrevatel.com/life/18653-zmist-propagandina-suchasnomu-etapi.htm

17. Babchenko A. Putin'ska propaganda distal z lyudey vsyu gigotu [Putin's propaganda received from people all the abominations]. Available at: http://socportal.info/2016/05/01/putins-ka-propaganda-distala-z-lyudej-vsyugidotu-babchenko.html\#

18. Putin protiv zakona o zaprete stsen nasiliya v SMI [Putin against law on ban of violence's scenes in media]. Available at: http://moral.ru/news/04_1222_ Putin_smi.htm

19. Akhmetov A.A. Separatizm v Rossii i na postsovetskom prostranstve i puti ego preodoleniya: dis. kand. politicheskikh nauk [Separatism in Russia and in postsoviet area and the ways of its overcoming. PhD in Law Diss.]. Moscow, 2013, 184 p. Available at: http://www.dissercat.com/content/separatizm-v-rossii-i-napostsovetskom-prostranstve-i-puti-ego-preodoleniya

20. Staravoytova G. Natsional'noe samoopredelenie: podkhody i izuchenie sluchayev [National identification: approaches and studying of the cases]. Moscow, 2002. Available at: http://www.vehi.net/politika/starovoit/02.html

21. Granitsy ne vechny: V Gosdume zagovorili o neobkhodimosti zakhvata territoriyi Kazakhstana i Ukrainy [Borders are not eternal: State Duma is said on necessity to occupy territories of Kazakhstan and Ukraine]. Available at: http://nv.ua/world/countries/granitsy-ne-vechny-v-gosdume-zajavili-o-neobhodi mosti-zahvata-territorij-kazahstana-i-ukrainy-546925.html

22. Kak zhivetsya $\mathrm{v}$ Donetske posle dvukh let $\mathrm{v}$ "DNR" [How is lived in Donetsk after two years in "DPR"] Available at: http://hronika.info/ obwestvo/141857-kak-zhivetsya-v-donecke-posle-dvuh-let-v-dnr.html

23. Friz I. Chto oznachayut slova Shoigu ob "umnoy i gramotnoy propagande" [What means the words of Shoigu on "intelligent and competent propaganda"] Available at: http://112.ua/mnenie/chto-oznachayut-slova-shoygu-ob-umnoy-igramotnoy-propagande-373742.html 